\title{
Fall-related injuries among youth under 20 years old who were treated in Nicaraguan emergency departments, 2004
}

\author{
María de Lourdes Martínez-Trujillo, MD, (I) Julio Rocha-Castillo, MPH, (2) \\ Carme Clavel-Arcas, MD, (3) Karin A Mack, PhD.(4)
}

Martínez-Trujillo ML, Rocha-Castillo J, Clavel-Arcas C, Mack KA.
Fall-related injuries among youth under 20 years old
who were treated in Nicaraguan emergency
departments, 2004.
Salud Publica Mex 20I I;53:I I6-124.

\begin{abstract}
Objective. To describe the circumstances of fall-related injuries among youth 0-19 years treated in emergency departments in Nicaragua; to estimate the incidence rates (IR) of falls; and, to identify areas for prevention efforts. Materials and Methods. All patients $<20$ years who were residents of Managua, León, Jinotepe, and Ciudad Sandino (6 593) were selected for analysis. Data were collected with the 2004 Injury Surveillance System. Results. In 2004, the IR of falls for youth $<20$ years old was 104.2 incidents per 10000 persons. The IR for male youth was twice that of female youth. Overall, trees $(23.3 \%)$ and beds (I5.2\%) were the main objects involved in falls. Fractures were the leading injuries sustained. Conclusions. This study identifies three areas that can be addressed: furniture, recreation, and physical environment. Interventions that may be most useful for caregivers and adolescents include changes in the home environment and recreation play areas, as well as educational programs.
\end{abstract}

Keywords: accidental falls; youth; adolescents; Nicaragua
Martínez-Trujillo ML, Rocha-Castillo J, Clavel-Arcas C, Mack KA. Lesiones relacionadas con caídas en menores de 20 años de edad que fueron tratados en departamentos de emergencias de Nicaragua, 2004.

Salud Publica Mex 20I 1;53:1 16-124.

\section{Resumen}

Objetivo. Describir las lesiones relacionadas con caídas entre los niños y adolescentes menores de 20 años de edad que fueron tratados en departamentos de emergencia de Nicaragua, 2004. Describir las circunstancias y estimar la tasa de incidencia (TI) de las caídas entre niños y adolescentes de 0-19 años atendidos en las salas de emergencia en Nicaragua. Además, identificar áreas dónde dirigir los esfuerzos de prevención. Materiales y métodos. Se seleccionaron todos los pacientes (6 593) de 0-19 años lesionados por caídas atendidos en emergencia por el Sistema de Vigilancia de Lesiones en 2004 en las ciudades de Managua, León, Jinotepe y Ciudad Sandino. Resultados. En 2004, la TI para caídas en niños y adolescentes $0-19$ años fue 104.2 por 10000 habitantes. La $\mathrm{TI}$ en varones fue dos veces más alta que en mujeres. Los principales objetos involucrados fueron árboles $(23.3 \%)$ y camas (I5.2\%). La principal naturaleza de lesión fue fractura (35.7\%). Conclusiones. Mobiliario, lugares de recreación y ambiente físico fueron las áreas identificadas. Desarrollar intervenciones incluyendo cambios en el ambiente del hogar y áreas recreacionales, así como programas educacionales, resulta muy útil para adolescentes y cuidadores.

Palabras clave: caídas accidentales; niños; adolescentes; Nicaragua

The findings and conclusions in this report are those of the author(s) and do not necessarily represent the official position of the Centers for Disease Control and Prevention and the Agency for Toxic Substances and Disease Registry.

(I) Universidad Nacional Autónoma de Nicaragua, Facultad de Ciencias Médicas, UNAN. León Nicaragua.

(2) Hospital Escuela Oscar Danilo Rosales (HEODRA). León, Nicaragua.

(3) Agencia Española de Cooperación Internacional para el Desarrollo (AECID). Managua, Nicaragua.

(4) National Center for Injury Prevention and Control, Centers for Disease Control and Prevention. Atlanta, GA, USA.

Received on: November I, 2010 • Accepted on: January 14,2011

Address reprint requests to: Karin Mack. National Center for Injury Prevention and Control, Centers for Disease Control and Prevention. 4770 Buford Hwy NE, F62, Atlanta, GA, USA.

E-mail:kim9@cdc.gov 
A round the world an estimated 46894 children and adolescents age 0-19 years died from fallrelated injuries in 2004. ${ }^{1}$ High-income countries in the Americas, Europe and Western Pacific regions have average fall mortality rates of between 0.2 and 1.0 per 100000 children less than 20 years old. Comparatively, low-income and middle-income countries in the same regions reported rates up to three times higher.

Further, as noted in Peden et al. in most countries falls are the most common type of childhood injury seen in emergency departments. ${ }^{1}$ Fall-related injuries contribute substantially to expenditures by both health care systems and individuals. Though the extent of the burden of injury is substantial, injuries receive inadequate public attention. A disparity exists between the funds allocated and the magnitude of injury burden as compared to the burden of other diseases. ${ }^{2-4}$

In low- and middle-income countries, information on falls among children and adolescents is lacking, ${ }^{1,5}$ and Nicaragua is no exception. This study tries to fill the gap of information about falls among children in $\mathrm{Ni}$ caragua through the following objectives: 1 ) to describe the circumstances of those injuries; 2) to estimate the incidence rates (IR) of fall injuries treated in EDs, and; 3) to indicate potential prevention action areas.

\section{Material and Methods}

\section{Study area and population}

This study included four important municipalities in Nicaragua: Managua, which is the capital of Nicaragua; León, which is the second largest urban center in the country, and; Jinotepe and Ciudad Sandino, which are located $46 \mathrm{~km}$ and $12.5 \mathrm{~km}$ from the capital, respectively. These four municipalities are located in the Pacific region of Nicaragua, which has the greatest population density. In 2004, the population of persons younger than 20 years old was 487401 in Managua, 91344 in León, 21242 in Jinotepe and 32331 in Ciudad Sandino. These populations represent $21.5 \%$ of Nicaragua's total number of persons younger than 20 years old. The population density varies from 150 inhabitants / $\mathrm{km}^{2}$ in Jinotepe to 3509 inhabitants $/ \mathrm{km}^{2}$ in Managua, corresponding to 3 to 82 times more than the average population density in Nicaragua.

\section{Sources of data}

The Centers for Disease Control and Prevention (CDC) and the Pan American Health Organization (PAHO), in coordination with the Health Ministry of Nicaragua, supported the establishment and development of the
Injury Surveillance System (ISS), which is described in detail in a previous report (including information about pilot work, the emergency department surveillance form, and staff training). ${ }^{6}$ Briefly, the ISS started in Nicaragua in 2001 with the participation of two hospitals and grew to include four public hospitals. Two hospitals, both of national importance, are located in Managua (Fernando Vélez Paiz, a children's hospital, and Antonio Lenin Fonseca), a third is located in León (Oscar Danilo Rosales) and the fourth is in Jinotepe (Regional). Only falls among residents in Managua, León, Jinotepe, and Ciudad Sandino were analyzed. Cuidad Sandino residents were included because they seek treatment in Managua.

There were 70240 overall emergency department (ED) visits by children and adolescents age $0-14$ years in 2004, with 13426 being seen for nonfatal unintentional injuries (rate of 191.1 per 1 000). The ISS included data for all persons seen for any type of injury in the ED. For this study, cases included all patients younger than 20 years old who sought medical attention in the ED for non-fatal falls during 2004 and who lived in one of the four municipalities. Falls from animals and transport vehicles, and falls into a fire were excluded from the study because they are classified as transport-related and burn-related injuries. There were 84 falls from animals, 434 falls from transport vehicles in motion, and 3 falls into a fire.

\section{Data collection and analysis}

A data collection form ${ }^{6}$ was designed specifically for the ISS and is now the official document of the ED. The form has four sections for collecting the following: 1) sociodemographic data (age, sex, residence); 2) general injury information (intent, place, activity, and mechanism [e.g., transport-related, blunt force, fall, poisoning]); 3) clinical data (alcohol use, body region, nature, severity) and case disposition (treated and discharged, admitted to the hospital, etc.), and; 4) additional information specific to particular injuries. For instance, for transport-related injuries, factors such as mode of transport (on foot, bicycle, car), the role of the injured person (driver, passenger), and safety elements (use of seat belt, helmet, child safety seat) are recorded. Severity is defined by the type of injury. For example, minor injuries are bruises and cuts, moderate injuries are fractures or sutures, and severe injuries include internal hemorrhage, punctured organs and severed blood vessels. The form also includes a notes field where the physician can document other relevant details of the injury event.

The first contact for the injured person in the ED is with the admissions worker, who completes the first 
section of the data collection form. The attending physician fills out the next three sections and records notes, as appropriate. The form is then sent to the epidemiology department for review. If data are incomplete or unclear, the form is returned to the emergency admissions worker or physician for correction. Finally, the epidemiology department sends the form to the statistics department where information is entered into a database. Staff was trained in both the use of the system and injury epidemiology. Participants in the training included doctors, emergency medicine staff, hospital epidemiologists, and local health department staff.

Data were cleaned and analyzed using the computer program Epi Info 3.3.2 (Atlanta: Centers for Disease Control). Variables used in the analyses were age, sex, place injured, activity, body region, and diagnosis of the case. Variables with missing data included place (12.3\%), activity $(14.4 \%)$, severity score $(0.6 \%)$, mechanism $(2 \%)$, body region $(1.1 \%)$, and diagnosis $(0.1 \%)$. The narratives in the record of each patient were reviewed and coded to obtain the circumstances and objects involved in the falls. In approximately $75 \%$ of the falls, either no object was involved or it could not be determined, particularly for falls on the same level, which contributed a little more than $50 \%$ of unclassified objects. The incidence rate (IR [per 10 000]) and 95\% confidence intervals (CI) were calculated by using the number of children injured in falls as the numerator and the population of each municipality as the denominator.

\section{Results}

In 2004, 6593 children and adolescents younger than 20 years old were seen in EDs for fall-related injuries. This number represents $51 \%$ of all falls (12 940) seen in the EDs.

\section{Incidence rate (IR)}

Overall, the IR was 104.2 incidents per 10000 inhabitants (Table I; CI 101.7-106.7). The IR for Jinotepe was nearly twice that of León and Managua and 8 times greater than that of Ciudad Sandino. The IR for male children was twice that of female children (138.1 vs. 72 per 10 000). Overall in females, the IR was higher for those younger than 5 years old (108.3 per 10000$)$ than for those older than 5 years; while, in males, the IR was highest among those aged 5-9 years (168.2 per 10000$)$.

Table I

Fall incidence Rates* by municipality, age group, and SEX. InJURY SURVeillance System, Nicaragua, 2004

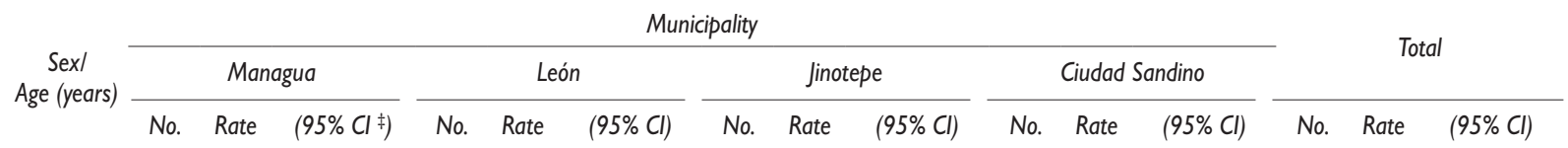

Female

\begin{tabular}{|c|c|c|c|c|c|c|c|c|c|c|c|c|c|c|c|}
\hline $0-4$ & 680 & 112.0 & $103.6-120.4$ & 109 & 95.8 & $77.9-1 \mid 3.7$ & 51 & 192.8 & | $40.4-245.2$ & 13 & 32.3 & 14.8-49.9 & 853 & 108.3 & $101.1-115.5$ \\
\hline $5-9$ & 599 & 96.2 & $88.6-103.9$ & $|5|$ & 129.5 & $108.9-150.0$ & 45 & 165.9 & $117.8-214.0$ & 7 & 17.0 & $4.4-29.6$ & 802 & 99.3 & $92.5-106.2$ \\
\hline $10-14$ & 356 & 56.3 & $50.5-62.2$ & 81 & 68.4 & $53.5-83.2$ & 28 & 101.7 & $64.2-139.2$ & 4 & 9.5 & $0.2-18.9$ & 469 & 57.2 & $52.0-62.4$ \\
\hline $15-19$ & 129 & 20.3 & $16.8-23.8$ & 51 & 42.8 & 3I.I-54.5 & 22 & 79.4 & $46.3-112.5$ & 5 & 11.9 & 1.4-22.3 & 207 & 25.1 & $21.7-28.5$ \\
\hline Subtotal & I 764 & 70.6 & 67.3-73.9 & 392 & 83.8 & $75.5-92.0$ & 146 & 134.2 & II 2.6-155.8 & 29 & 17.5 & II.I-23.9 & 2331 & 72.0 & $69.0-74.9$ \\
\hline
\end{tabular}

Male

\begin{tabular}{lrrlllllllllllll}
$0-4$ & 919 & 158.8 & $148.6-169.0$ & 176 & 162.3 & $138.5-186.1$ & 69 & 273.7 & $210.0-337.3$ & 12 & 31.3 & $13.6-49.0$ & 1176 & 156.7 & $147.8-165.6$ \\
\hline $5-9$ & 968 & 163.2 & $153.0-173.4$ & 220 & 198.0 & $172.0-223.9$ & 95 & 367.6 & $295.0-440.2$ & 11 & 28.0 & $11.4-44.6$ & 1294 & 168.2 & $159.1-177.3$ \\
\hline $10-14$ & 1018 & 169.1 & $158.8-179.4$ & 195 & 172.9 & $148.8-196.9$ & 65 & 247.8 & $188.3-307.3$ & 11 & 27.6 & $11.3-43.9$ & 1289 & 165.1 & $156.2-174.0$ \\
\hline $15-19$ & 338 & 55.8 & $49.9-61.7$ & 101 & 89.0 & $71.7-106.3$ & 50 & 189.5 & $137.5-241.5$ & 14 & 34.9 & $16.6-53.2$ & 503 & 64.0 & $58.4-69.6$ \\
\hline Subtotal & 3243 & 136.3 & $131.6-141.0$ & 692 & 155.2 & $143.7-166.7$ & 279 & 269.1 & $237.9-300.3$ & 48 & 30.5 & $21.8-39.1$ & 4262 & 138.1 & $134.0-142.2$ \\
\hline Total & 5007 & 102.7 & $99.8-105.5$ & $\mid 1084$ & $|1| 8.6$ & $|1| 1.6-125.6$ & 425 & 200.0 & $181.2-218.9$ & 77 & 23.8 & $18.5-29.2$ & 6593 & 104.2 & $101.7-106.7$
\end{tabular}

* Rate per 10000 inhabitants in the same age group

$\ddagger \mathrm{Cl}=$ confidence interval 
The rate for males in León and Jinotepe was also highest for those 5-9 years, while in Managua it was highest for those 10-14 years, and in Ciudad Sandino it was highest for those 15-19 years. The rate for females was highest for those 5-9 years old in León and Ciudad Sandino, and in Managua and Jinotepe it was highest for those $0-4$ years old.

\section{Circumstances}

Of the falls that could be classified, most occurred at the same level (51.6\%) followed by falls from a height (43.2\%; Table II). For falls involving an object, the leading objects involved were trees (23.3\%), beds (15.2\%) and chairs $(7.3 \%)$. The vast majority of falls happened at home $(67.8 \%)$ and involved children playing or resting $(81.4 \%)$. The majority of falls on ground level (51.7\%) were rated mild in severity and $47.6 \%$ were rated moderate, leaving 0.4 categorized as severe. The majority $(59.7 \%)$ of falls from a height were rated moderate in severity, $39.1 \%$ were rated mild, and $0.7 \%$ severe.

\section{Rank by age}

For children younger than 1 year old, beds $(21 \%)$, cradles $(8.5 \%)$, hammocks $(7.4 \%)$ and chairs $(7.4 \%)$ were ranked

Table II

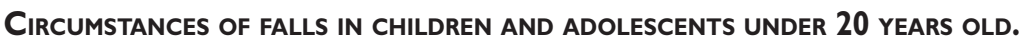
Injury Surveillance System, Nicaragua, 2004

\begin{tabular}{|c|c|c|c|c|c|c|c|c|c|c|c|}
\hline Mechanism & Count & Percent & Object & Count & Percent & Place & Count & Percent & Activity & Count & Percent \\
\hline Same level & 2567 & 51.6 & Tree & 417 & 23.3 & Home & 4207 & 67.8 & Playing/resting & 5015 & 81.4 \\
\hline Fall from height & 2149 & 43.2 & Bed & 271 & 15.2 & Street & 1340 & 21.6 & Walking & 313 & 5.1 \\
\hline Fall by slip & 111 & 2.2 & Chair & 130 & 7.3 & School & 484 & 7.8 & Working & 173 & 2.8 \\
\hline Fall into & 47 & 0.9 & Stairs/step & 121 & 6.8 & Work & 83 & 1.3 & Sports & 172 & 2.8 \\
\hline Fall by trip & 47 & 0.9 & Football & 109 & 6.1 & Others & 91 & 1.5 & Studying & 124 & 2.0 \\
\hline Fall by push & 29 & 0.6 & Hammock & 89 & 5.0 & Subtotal & 6205 & 100 & Drinking & 21 & 0.3 \\
\hline Fall when being held & 26 & 0.5 & Wall/fence & 89 & 5.0 & Unclassified & 388 & & Others & 341 & 5.5 \\
\hline Subtotal & 4976 & 100 & Bath & 49 & 2.7 & Total & 6593 & & Subtotal & 6159 & 100 \\
\hline Unclassified & 1617 & & Swing & 47 & 2.6 & & & & Unclassified & 434 & \\
\hline \multirow[t]{24}{*}{ Total } & 6593 & & Ditch/hole & 45 & 2.5 & & & & Total & 6593 & \\
\hline & & & Table & 44 & 2.5 & & & & & & \\
\hline & & & Sidewalk & 41 & 2.3 & & & & & & \\
\hline & & & Roof & 34 & 1.9 & & & & & & \\
\hline & & & Cradle & 34 & 1.9 & & & & & & \\
\hline & & & Skate & 27 & 1.5 & & & & & & \\
\hline & & & Being held & 26 & 1.5 & & & & & & \\
\hline & & & Vehicle stopped & 24 & 1.3 & & & & & & \\
\hline & & & Play equipment & 24 & 1.3 & & & & & & \\
\hline & & & Basketball & 22 & 1.2 & & & & & & \\
\hline & & & Baseball & 18 & 1.0 & & & & & & \\
\hline & & & Walker & 15 & 0.8 & & & & & & \\
\hline & & & Bathroom & 14 & 0.8 & & & & & & \\
\hline & & & Bridge & 14 & 0.8 & & & & & & \\
\hline & & & Physical education & 13 & 0.7 & & & & & & \\
\hline & & & Window & 9 & 0.5 & & & & & & \\
\hline & & & Cliff/precipice & 6 & 0.3 & & & & & & \\
\hline & & & Seizure & 4 & 0.2 & & & & & & \\
\hline & & & Dancing & 4 & 0.2 & & & & & & \\
\hline & & & Pool & 4 & 0.2 & & & & & & \\
\hline & & & Others specified & 42 & 2.4 & & & & & & \\
\hline & & & Subtotal & 1786 & 100 & & & & & & \\
\hline & & & Unclassified & 4807 & & & & & & & \\
\hline & & & Total & 6593 & & & & & & & \\
\hline
\end{tabular}


as the leading products involved in falls (Table III). Also, in this age group falls from trees began to occur (ranked \#7). Just as they did for children younger than 1 year old, beds $(7 \%)$ continued to rank first place among children aged 1-4 years. However, for children aged 1-4 years, the second, third, and fourth positions changed to chairs $(3.5 \%)$, trees $(2.4 \%)$, and stairs $(1.9 \%)$, respectively. For children aged 5-9 years, falls from trees ranked first, beds second, and falls from stairs ranked third. For children and adolescents aged 10-14 years and 15-19 years, falls from trees ranked first, falls during football (soccer) second, and stairs third.

\section{Nature and body region}

The leading types of injuries sustained overall during falls were fractures $(35.7 \%)$, contusions $(22.3 \%)$, and open wounds $(15.2 \%)$ (Table IV). This pattern was simi-

Table III

Leading products involved in falls, by age group. Injury Surveillance System, Nicaragua, 2004

\begin{tabular}{|c|c|c|c|c|c|}
\hline \multirow[b]{2}{*}{ Rank } & \multicolumn{5}{|c|}{ Age in years } \\
\hline & $\begin{array}{c}<1 \\
(n=176)\end{array}$ & $\begin{array}{c}I-4 \\
(n=I 853)\end{array}$ & $\begin{array}{c}5-9 \\
(n=2096)\end{array}$ & $\begin{array}{c}10-14 \\
(n=1758)\end{array}$ & $\begin{array}{c}15-19 \\
(n=710)\end{array}$ \\
\hline I & Bed & Bed & Tree & Tree & Tree \\
\hline No. & 37 & 130 & 182 & 156 & 27 \\
\hline Percent & 21.0 & 7.0 & 8.7 & 8.9 & 3.8 \\
\hline 2 & Cradle & Chair & Bed & Football & Football \\
\hline No. & 15 & 65 & 76 & 69 & 25 \\
\hline Percent & 8.5 & 3.5 & 3.6 & 3.9 & 3.5 \\
\hline 3 & Hammock & Tree & Stairs & Stairs & Stairs \\
\hline No. & 13 & 45 & 41 & 27 & 14 \\
\hline Percent & 7.4 & 2.4 & 2.0 & 1.5 & 2.0 \\
\hline 4 & Chair & Stairs & Wall/fence & Bed & Basketball \\
\hline No. & 13 & 35 & 38 & 24 & 13 \\
\hline Percent & 7.4 & 1.9 & 1.8 & 1.4 & 1.8 \\
\hline 5 & Held & Hammock & Hammock & Wall/fence & Roof \\
\hline No. & 8 & 32 & 30 & 22 & 10 \\
\hline Percent & 4.5 & 1.7 & 1.4 & 1.3 & 1.4 \\
\hline 6 & Walker & Bath & Chair & Chair & Ditch/hole \\
\hline No. & 7 & 27 & 27 & 21 & 6 \\
\hline Percent & 4.0 & 1.5 & 1.3 & 1.2 & 0.8 \\
\hline 7 & Tree & Wall/fence & Swing & Ditch/hole & Baseball \\
\hline No. & 7 & 25 & 23 & 16 & 5 \\
\hline Percent & 4.0 & 1.3 & I.I & 0.9 & 0.7 \\
\hline 8 & Stairs & Table & Ditch/hole & Roof & Bed \\
\hline No. & 4 & 24 & 15 & 16 & 4 \\
\hline Percent & 2.3 & 1.3 & 0.7 & 0.9 & 0.6 \\
\hline 9 & Bath & Sidewalk & Bath & Swing & Chair \\
\hline No. & 2 & 17 & 14 & 14 & 4 \\
\hline Percent & 1.1 & 0.9 & 0.7 & 0.8 & 0.6 \\
\hline 10 & Table & Cradle & Football & Hammock & Sidewalk \\
\hline No. & 2 & 16 & 14 & 14 & 4 \\
\hline Percent & I.I & 0.9 & 0.7 & 0.8 & 0.6 \\
\hline
\end{tabular}


Table IV

NATURE AND body REGION OF FALL INJURIES IN CHILDREN AND ADOLESCENTS UNDER 20 YEARS OLD. InJury Surveillance System, Nicaragua, 2004

\begin{tabular}{|c|c|c|c|c|c|c|c|c|c|c|c|c|}
\hline \multirow{3}{*}{ Nature and body region } & \multicolumn{12}{|c|}{ Age (years) } \\
\hline & \multicolumn{2}{|c|}{$\begin{array}{c}<1 \\
(n=176)\end{array}$} & \multicolumn{2}{|c|}{$\begin{array}{c}1-4 \\
(n=\mid 853)\end{array}$} & \multicolumn{2}{|c|}{$\begin{array}{c}5-9 \\
(n=2096)\end{array}$} & \multicolumn{2}{|c|}{$\begin{array}{c}10-14 \\
(n=1758)\end{array}$} & \multicolumn{2}{|c|}{$\begin{array}{l}15-19 \\
(n=710)\end{array}$} & \multicolumn{2}{|c|}{$\begin{array}{c}\text { Total } \\
(n=6593)\end{array}$} \\
\hline & No. & $\%$ & No. & $\%$ & No. & $\%$ & No. & $\%$ & No. & $\%$ & No. & $\%$ \\
\hline Fracture & 32 & 18.1 & 520 & 28.1 & 853 & 40.7 & 808 & 46.0 & 145 & 20.4 & 2358 & 35.7 \\
\hline arm and hand & 19 & 59.4 & 365 & 70.2 & 683 & 80.1 & 638 & 79.0 & 91 & 62.8 & 1796 & 76.2 \\
\hline head and neck & 4 & 12.5 & 13 & 2.5 & 18 & 2.1 & 9 & 1.1 & 7 & 4.8 & 51 & 2.2 \\
\hline legs and feet & 7 & 21.9 & 60 & 11.5 & 90 & 10.6 & 113 & 14.0 & 30 & 20.7 & 300 & 12.7 \\
\hline upper trunk & 2 & 6.3 & 73 & 14.0 & 47 & 5.5 & 36 & 4.5 & 8 & 5.5 & 166 & 7.0 \\
\hline others specified & - & - & 7 & 1.3 & 14 & 1.6 & 11 & 1.4 & 7 & 4.8 & 39 & 1.7 \\
\hline unclassified & - & - & 2 & 0.4 & I & 0.1 & I & 0.1 & 2 & 1.4 & 6 & 0.3 \\
\hline Contusion & 10 & 5.7 & 376 & 20.1 & 439 & 21.0 & 421 & 24.0 & 229 & 32.2 & 1475 & 22.3 \\
\hline arm and hand & I & 10.0 & 169 & 44.9 & 231 & 52.6 & 236 & 56.1 & 92 & 40.2 & 729 & 49.4 \\
\hline head and neck & 4 & 40.0 & 81 & 21.5 & 57 & 13.0 & 27 & 6.4 & 24 & 10.5 & 193 & 13.1 \\
\hline legs and feet & 4 & 40.0 & 89 & 23.7 & 97 & 22.1 & 109 & 25.9 & 67 & 29.3 & 366 & 24.8 \\
\hline upper trunk & I & 10.0 & II & 2.9 & 14 & 3.2 & 22 & 5.2 & 21 & 9.2 & 69 & 4.7 \\
\hline others specified & - & - & 23 & 6.1 & 36 & 8.2 & 21 & 5.0 & 16 & 7.0 & 96 & 6.5 \\
\hline unclassified & - & - & 3 & 0.8 & 4 & 0.9 & 6 & 1.4 & 9 & 3.9 & 22 & 1.5 \\
\hline Wound & 14 & 7.9 & 356 & 19.2 & 363 & 17.3 & 173 & 9.8 & 102 & 14.3 & 1008 & 15.2 \\
\hline arm and hand & 3 & 21.4 & 13 & 3.7 & 33 & 9.1 & 40 & 23.1 & 18 & 17.6 & 107 & 10.6 \\
\hline head and neck & 10 & 71.4 & 313 & 87.9 & 256 & 70.5 & 71 & 41.0 & 59 & 57.8 & 709 & 70.3 \\
\hline legs and feet & I & 7.1 & 24 & 6.7 & 53 & 14.6 & 55 & 31.8 & 14 & 13.7 & 147 & 14.6 \\
\hline upper trunk & - & - & 4 & 1.1 & 7 & 1.9 & 2 & 1.2 & 7 & 6.9 & 20 & 2.0 \\
\hline others specified & - & - & I & 0.3 & 7 & 1.9 & 3 & 1.7 & 3 & 2.9 & 14 & 1.4 \\
\hline unclassified & - & - & I & 0.3 & 7 & 1.9 & 2 & 1.2 & 1 & 1.0 & II & 1.4 \\
\hline Head trauma & 104 & 59.1 & 395 & 21.3 & 235 & 11.2 & 144 & 8.2 & 63 & 8.8 & 941 & 14.2 \\
\hline Strain, sprain & 9 & 5.1 & 107 & 5.7 & 118 & 5.6 & 155 & 8.8 & 129 & 18.1 & 518 & 7.8 \\
\hline arm and hand & 3 & 33.3 & 58 & 54.2 & 36 & 30.5 & 40 & 25.8 & 37 & 28.7 & 174 & 33.6 \\
\hline legs and feet & 6 & 66.7 & 46 & 43.0 & 78 & 66.1 & 110 & 71.0 & 89 & 69.0 & 329 & 63.5 \\
\hline others specified & - & - & 3 & 2.8 & 4 & 3.4 & 5 & 3.2 & 3 & 2.3 & 15 & 2.9 \\
\hline Other nature & 7 & 3.9 & 99 & 5.3 & 88 & 4.1 & 57 & 3.2 & 42 & 5.9 & 293 & 4.4 \\
\hline arm and hand & & & 16 & 16.2 & 9 & 10.2 & 18 & 31.6 & II & 26.2 & 54 & 18.4 \\
\hline head and neck & 5 & 71.4 & 65 & 65.7 & 45 & 51.1 & 7 & 12.3 & 9 & 21.4 & $|3|$ & 44.7 \\
\hline legs and feet & I & 14.3 & 8 & 8.1 & 13 & 14.8 & 22 & 38.6 & 10 & 23.8 & 54 & 18.4 \\
\hline upper trunk & I & 14.3 & I & 1.0 & 4 & 4.5 & 2 & 3.5 & 9 & 21.4 & 17 & 5.8 \\
\hline others specified & - & - & 4 & 4.0 & 14 & 15.9 & 7 & 12.3 & 2 & 4.8 & 27 & 9.2 \\
\hline unclassified & - & - & 5 & 5.1 & 3 & 3.4 & I & 1.8 & I & 2.4 & 10 & 3.4 \\
\hline
\end{tabular}


lar among children and adolescents aged 5-14 years. For children younger than 1 year old, head trauma (59\%) was the leading type of injury sustained during falls, while in children aged 1-4 years, head trauma occupied second place (21.3\%). Of all fractures, $76.1 \%$ affected arms and hands. Among children younger than 1 year old, contusions occurred in the head and neck and in the legs and feet. In general, $70.3 \%$ of open wounds affected the head and neck.

\section{Discussion}

The ISS in Nicaragua has shown that injuries are an important cause of medical attention in emergency departments, that falls are a leading cause of injuries, ${ }^{6,7}$ and that, for children, falls are the leading cause of nonfatal injury. ${ }^{8}$ Falls bring 18 children and adolescents a day to the ED in Nicaragua. Children are injured in falls, for example, when they trip and fall to the ground (on the same level), or when they lose their balance and fall from a height such as a window, ledge, or off furniture. The nature of the injury sustained during a fall depends on many relevant factors, including height (or distance) of the fall, impact surface, landing position/body orientation, velocity, mass, and age. The current study, based on data from the 2004 ISS, examined in detail fall injuries occurring in four municipalities in Nicaragua among children and adolescents younger than 20 years old. This study is the first to estimate the IR of falls and to determine possible areas of intervention for this age group in Nicaragua.

The leading type of injury in this study was fracture, which is similar to findings in studies conducted in Aus- tralia, the United States, and the United Kingdom. 4, 9-11 Among the youngest group, head trauma was the most frequent type of injury sustained during falls, similar to research in other countries. ${ }^{11}$ Head trauma is particularly troubling, as demonstrated by a study in Bangladesh that found falls were the leading cause of disability for different durations, including permanent disability. ${ }^{12}$

This study identified three specific target areas for interventions (Table V) -recreation, furniture and the physical environment- and prevention messages could be structured around this conceptual map. For example, prevention activities targeted at recreation typically include sports and playground injury prevention, but this study demonstrates the importance of including other forms of recreation or play. The leading object involved in falls was a tree, similar to a study in Bangladesh. ${ }^{12}$ In Nicaragua, children play in trees and pick fruit. These circumstances are important because potential injury severity increases with the height of the fall, ${ }^{13,14}$ although even falls from low heights should be examined for the likelihood of unrecognized head injuries. ${ }^{9}$ Drawing upon lessons learned from playground falls could inform a tree fall prevention program, such as enhancing areas under trees with soft surfacing, such as mulch.

Injuries related to furniture items, such as beds and hammocks, were also prominent across age groups. Falls from beds have been identified in other studies as a key injury area. ${ }^{10,15,16}$ Preventing these falls likely requires enhanced product safety standards as well as education about preventing falls from heights.

Alterations to the physical environment can also help prevent injuries. For example, stairs can be made

Table V

INTERVENTION AREAS FOR CHILDREN AND ADOLESCENTS UNDER 20 YEARS OLD. Injury Surveillance System, Nicaragua, 2004

\begin{tabular}{|c|c|c|c|c|c|}
\hline \multirow{2}{*}{ Area for intervention } & \multicolumn{5}{|c|}{ Age in years } \\
\hline & $<1$ & $1-4$ & $5-9$ & $10-14$ & $15-19$ \\
\hline Recreation & & Tree & $\begin{array}{l}\text { Tree } \\
\text { Football } \\
\text { Swing }\end{array}$ & $\begin{array}{l}\text { Tree } \\
\text { Football } \\
\text { Swing }\end{array}$ & $\begin{array}{l}\text { Tree } \\
\text { Football } \\
\text { Baseball } \\
\text { Basketball }\end{array}$ \\
\hline Furniture & $\begin{array}{l}\text { Bed } \\
\text { Hammock } \\
\text { Cradle } \\
\text { Chair } \\
\text { Baby walker } \\
\text { Table } \\
\text { Bath }\end{array}$ & $\begin{array}{l}\text { Bed } \\
\text { Hammock } \\
\text { Chair } \\
\text { Cradle } \\
\text { Table } \\
\text { Bath }\end{array}$ & $\begin{array}{l}\text { Bed } \\
\text { Hammock } \\
\text { Chair } \\
\text { Bath }\end{array}$ & $\begin{array}{l}\text { Bed } \\
\text { Hammock } \\
\text { Chair }\end{array}$ & $\begin{array}{l}\text { Bed } \\
\text { Chair }\end{array}$ \\
\hline Physical environment & Stairs & $\begin{array}{l}\text { Stairs } \\
\text { Sidewalk } \\
\text { Wall/fence }\end{array}$ & $\begin{array}{l}\text { Stairs } \\
\text { Wall/fence } \\
\text { Ditch/hole }\end{array}$ & $\begin{array}{l}\text { Stairs Wall/fence } \\
\text { Ditch/hole } \\
\text { Roof }\end{array}$ & $\begin{array}{l}\text { Stairs } \\
\text { Sidewalk Ditch/hole } \\
\text { Roof }\end{array}$ \\
\hline
\end{tabular}


safer for children. Stair gates can be used to block access to stairs for the youngest children, and hand rails and adequate lighting may be safety enhancements for older children. Blocking stair access should begin at birth and caregivers should consider the risk of falls on stairs while carrying infants. ${ }^{15}$

Appropriate supervision, especially from caregivers, is necessary to prevent falls among children in any circumstance. One third of households in Nicaragua are female headed households, primarily single mothers. When these mothers leave for work, they often leave the care of their young children to older siblings (typically 7-16 years old). Moreover, these siblings have responsibility for household chores, which can detract from supervision quality. ${ }^{17,18}$ In addition, those chores (cooking over open fires, feeding chickens or ducks, collecting and preparing firewood, ironing clothes) are not without some risk. Lack of adequate supervision may increase the chance of suffering severe fall-related injuries. Caregiver attributes likely to decrease the risk of injury among children include use of positive reinforcement to promote safe behaviors, high awareness and knowledge of home safety measures, and appropriate supervision. ${ }^{19,20}$

This study has several limitations that should be considered. First, the study underestimates the true risk of non-fatal unintentional injury because some injuries will be treated in other health care situations or, appropriately or not, with home care, especially for those who cannot afford care or transportation to a medical facility. Inherently, only cases that present to a participating hospital are captured. Injuries treated in emergency departments, however, are likely to be those with the greatest impact on the individual, the health system, and household spending. The lower number of cases in Ciudad Sandino is likely influenced by the accessibility to a hospital. Some of the differences in IRs between regions may be due to transportation issues. Injured children in Ciudad Sandino must pay transportation expenditures to go to Managua hospitals and families may not have resources to travel the distance for treatment. On the other hand, Jinotepe is a small municipality, and the Regional Hospital is the only emergency medical center treating people injured in this municipality. The distance to the facility is therefore shorter and transportation costs may be lower. Comparing the IR found in this study for Nicaragua with that of other countries is challenging because of different methodologies, case definitions, age groups, and other factors..$^{21-24}$ Nevertheless, we can compare other facets of this study. We found that falls occurred mainly at the same level, which is consistent with findings in other countries 11,25 and is also likely related to physical structures. For example, children are more likely to play in the street and yard because playground equipment is not available. Several studies, including this one, found that falls occurred primarily at home. ${ }^{4,9,24,26,27}$

With regard to limits of the ISS measurements, two of the variables used in the analyses had $>10 \%$ missing data (place, $12.3 \%$ and activity, $14.4 \%$ ). While this limits the ability to understand the circumstances of the injuries, these percentages appear to perform better than other surveillances systems. Runyan, et al. report that between 8 and $41 \%$ of non-fatal unintentional injury cases in the United States had missing values for location depending upon the source. ${ }^{28}$ In addition, the injury severity measure used is a simple check category on the intake form. It is based on the physician's assessment and is not in a more commonly accepted and comparable form, such as the Glasgow or the Abbreviated Injury Scale. We recognize the limitations of the severity measure, however in lieu of a more robust measure in poor countries it may be considered useful and practical to classify injuries; ${ }^{29}$ added usefulness may also be forthcoming (for example, examining change in the measurement over time).

This analysis of children and adolescent falls identified areas for targeting prevention efforts (Table V). These areas could be used to prioritize programs, and interventions should be developed specific to these circumstances. While drawing upon established interventions or educational programs will be challenging given the lack of development of this area in the literature, Peden et al. (especially pp. 110-115) provide information on adapting interventions. ${ }^{1}$ New interventions will need to be developed, tested and evaluated, or known effective interventions adapted for local use. Strategies for prevention need the collaboration of local partnerships, such as the local health ministries in each municipality. The Nicaraguan Ministry of Health has medical care programs for mothers and children that could be used by local health workers to promote safety in the household. Educational programs about fall hazards conducted for caregivers, children, and adolescents could be a starting point. In addition, the Nicaraguan Ministry of Family could integrate fall safety programs into current activities. These strategies would be most effective if done through a collaboration that included government and non-governmental organizations and, most importantly, the family.

Declaration of conflicts of interest: The authors declare that they have no conflict of interests. 


\section{References}

I. Peden M, Oyegbite K, Ozanne-Smith J, Hyder A, Branche C, Rahman S, et al.World report on child injury prevention:World Health Organization, 2008.

2. World Health Organization. Child and adolescent injury prevention:A WHO plan of action 2006-20I5. Geneva:WHO, 2006.

3. Peden M, McGee K, Sharma G. The injury chart book:A graphical overview of the global burden of injuries. Geneva:World Health Organization, 2002.

4. Steenkamp M, Cripps R. Child injuries due to falls. Adeliade:Australian Institute of Health and Welfare, 200I.

5. Hyder AA, Sugerman D, Ameratunga S, Callaghan JA. Falls among children in the developing world: a gap in child health burden estimations? Acta Paediatr 2007;96(10):1394-1398.

6. Sklaver BA, Clavel-Arcas C, Fandino-Losada A, Gutierrez-Martinez MI, Rocha-Castillo J, de Garcia SM, et al. The establishment of injury surveillance systems in Colombia, El Salvador, and Nicaragua (2000-2006). Rev Panam Salud Publica 2008;24(6):379-389.

7. Espitia-Hardeman V, Rocha J, Clavel-Arcas C, Dahlberg L, Mercy JA, Concha-Eastman A. Characteristics of non-fatal injuries in Leon, Nicaragua - 2004. Int J Inj Contr Saf Promot 2007; 14(2):69-75.

8. Martinez TML, Rocha CJ, Clavel-Arcas C, Mack KA. Nonfatal unintentional injuries in children aged $<15$ years in Nicaragua. Int $\mathrm{J}$ Inj Contr Saf Promot 2010;17(I):3-II.

9. Kim KA, Wang MY, Griffith PM, Summers S, Levy ML. Analysis of pediatric head injury from falls. Neurosurg Focus 2000;8(I):e3. 10. Macgregor DM. Injuries associated with falls from beds. Inj Prev 2000;6(4):29I-292.

II. Pitone ML,Attia MW. Patterns of injury associated with routine childhood falls. Pediatr Emerg Care 2006;22(7):470-474

12. Chowdhury S, Rahman A, Rahman S, Giashuddin S, Svanstrom L, Horte L, et al. Childhood fall: Epidemiologic findings from a population based survey in Bangladesh. Int J Disabil Hum Dev 2008;7(I):8I-87.

13. Bulut M, Koksal O, Korkmaz A, Turan M, Ozguc H. Childhood falls: characteristics, outcome, and comparison of the Injury Severity Score and New Injury Severity Score. Emerg Med I 2006;23(7):540-545.

14. Zargar M, Khaji A, Karbakhsh M. Injuries causes by falls from trees in Tehran, Islamic Republic of Iran. Eastern Mediterranean Health Journal 2005; II.
15. Mack KA, Gilchrist J, Ballesteros MF. Injuries among infants treated in emergency departments in the United States, 200I-2004. Pediatrics 2008; I2I (5):930-937.

16. Tung TH, Liu MC, Yang JY, Syu WY, Wu HP. Useful methods in preventing accidental falls from the bed in children at the emergency department. Eur J Pediatr 2009; |68(II):I323-I326.

17. Dahlblom K, Herrara AR, Pena R, Dahlgren L. Home Alone: Children as Caretakers in Leon, Nicaragua. Children \& Society 2009;23(I):43-56. 18. Instituto Nacional de Estadisticas y Censos. VII Censo de poblacion y IV de Vivienda, 2005 Hogar, caracteristics generalas. Nicaragua: INEC, 2005. 19. Sleet D, Mercy J. Promotion of safety, security, and well-being. In: Bornstein M, Davidson L, Keyes C, Moore K, editors. Well-being: Positive development across the life course. Mahwah, NJ: Erlbaum, 2003:8I-98. 20. Mack KA, Sogolow E, Strouse D, Lipman PD. The role of supervision of children in injury prevention. Salud Publica Mex 2008;50 Suppl I:SI I2-4. 2I. Bar-Joseph N, Rennert G,Tamir A, Ore L, Bar-Joseph G. Ethnic differences in the epidemiological characteristics of severe trauma due to falls from heights among children in northern Israel. Isr Med Assoc J 2007;9(8):603-606

22. Lyons RA, Polinder S, Larsen CF, Mulder S, Meerding WJ, Toet H, et al. Methodological issues in comparing injury incidence across countries. Int J Inj Contr Saf Promot 2006;13(2):63-70.

23. Sugerman DE, Hyder AA, Nasir K. Child and young adult injuries among long-term Afghan refugees. Int J Inj Contr Saf Promot 2005; I2(3): I77-I82. 24. Ashby K, Corbo M. Child fall injuries: An overview.Victoria:Victorian Injury Surveillance \& Applied Research System, 2000.

25. Poudel-Tandukar K, Nakahara S, Ichikawa M, Poudel KC, Joshi AB, Wakai S. Unintentional injuries among school adolescents in Kathmandu, Nepal: a descriptive study. Public Health 2006; 120(7):64I-649.

26. Gawryszewski VP, Scarpelini S, Dib JA, Jorge MH, Pereira-Junior GA, Morita M. Atendimentos de emergencia por lesoes decorrentes de causas externas: caracteristicas das vitimas e local de ocorrencia, Estado de Sao Paulo, Brasil, 2005. Cad Saude Publica 2008;24(5): | | | | - I 29. 27. Moorin RE, Hendrie D. The epidemiology and cost of falls requiring hospitalisation in children in Western Australia: a study using linked administrative data. Accid Anal Prev 2008;40(I):216-222.

28. Runyan CW, Perkis D, Marshall SW, Johnson RM, Coyne-Beasley T, Waller $\mathrm{AE}$, et al. Unintentional injuries in the home in the United States Part II: morbidity. Am j Prev Med 2005;28(I):80-87.

29. Holder Y, Peden M, Krug E, Lund J, Gururaj G, Kobusingye O. Injury surveillance guidelines. Geneva:World Health Organization, 2001. 